\title{
Effectiveness of Large Woody Debris in Stream Rehabilitation Projects in Urban Basins
}

\author{
By Marit Larson, Center for Urban Water Resources Management
}

March 2000

\section{INTRODUCTION}

In-stream rehabilitation projects are commonly built in response to problems that result from both local sources and diffuse watershed degradation Local problems, such as an improperly sized culvert, are relatively easily identified and corrected. Reversing the consequences of watershed degradation, such as channel widening and incision, is much more difficult if conditions that led to stream degradation remain unchecked. Despite this challenge, large amounts of money are being spent on in-stream projects in urban or urbanizing basins, because of numerous recognized problems on these streams, the interest of local communities in restoring the amenities these streams provide (Riley 1998, MacDonald 1995), and the relative ease and economy of site-specific in-stream work.

This study investigates the effectiveness of one common technique, placement of in-stream large woody debris (LWD), to reverse local effects of watershed degradation in the absence of any systematic watershed-scale rehabilitation measures. To accomplish this, six stream rehabilitation projects in western Washington state that employ LWD were examined with the objective of answering the following questions:

- Does in-stream placement of LWD produce physical channel characteristics typical of streams in less-disturbed watersheds?

- Does biological integrity improve after LWD is added?

- How can LWD project designs be improved?

- Does watershed-scale disturbance, generally unaffected by LWD projects, extent an equivalent or greater effect on the physical and biological recovery of the channel than the local in-channel conditions that are addressed by the LWD?

\section{The use of LWD in channel enhancement}

LWD plays prominent roles in regulating channel morphology and habitat in the Pacific Northwest, from steep and narrow headwater streams to wide low-gradient rivers. These functions make it a critical component of current stream and river restoration and enhancement efforts. The effects of LWD on moderate-gradient streams (0.5-4\% slope) with bankfull widths of about 4-40 $\mathrm{m}$ have been studied in greatest detail. The steeper of these channels, dominated by riffle and glide features, are classified as "plane-bed" by Montgomery and Buffington (1997). Lower-gradient streams commonly display regularly alternating riffles and pools in a meandering planiform. The transition from "plane-bed" to these flatter "pool-riffle" channels, under a particular sediment-supply and flow regime, can be controlled by the presence of LWD or other obstructions that form scour pools, bars, sediment storage sites, and steps in channels that would otherwise maintain a relatively uniform, planar bed. In these channels, LWD can influence bank stability, pool and bar formation, sediment retention, and grade (Montgomery et al. 1995, Beechie and Sibley 1997, Nelson 1998).

Several constraints increase the difficulty of returning LWD to streams in urban systems. In most urban basins there is little possibility of restoring natural LWD recruitment. 
Opportunities for allowing LWD to influence channel morphology are also limited by channel confinement and constrictions. The proximity of structures and property to the channel also limits any tolerance for the random development of log jams, intermittent channel widening, debris entrapment, backwater, or LWD movement. The integration of LWD into urban systems also requires gaining acceptance and educating the community at a level not necessary when working in remote areas.

\section{APPROACH AND METHODS Study Sites}

To investigate whether in-stream structures can mitigate the impacts of watershed urbanization, six in-stream rehabilitation projects were examined in watersheds that span a range of watershed development intensities (Table 1), and that generally identified "habitat enhancement" as a primary or secondary goal. Development intensity in the watershed area contributing to each project was determined from GIS land cover data layers based on 1995 Landsat satellite imagery classified by King County Land and Water Resources Division (Jeff Burke writ. comm., 1998) at 30-m resolution. For this analysis, land cover was considered developed if classified as "high," "medium," or "low-intensity" development; "bare rock/concrete," "bare ground/asphalt," and "recently cleared" land (Table 2).

Table 1. Project Characteristics

\begin{tabular}{|c|c|c|c|c|c|c|}
\hline & Forbes & Thornton & Swamp & H. Hills & L. Jacob's & Soosette \\
\hline Project Characteristics & \multicolumn{3}{|c|}{ ANCHORED LWD } & \multicolumn{3}{|c|}{ UNANCHORED LWD } \\
\hline Year constructed & 1988 & 1997 & 1997 & 1996 & 1995 & 1994 \\
\hline Project length (m) & 210 & 280 & 370 & 240 & 430 & 1430 \\
\hline LWD placement & $\begin{array}{l}\text { cabled and } \\
\text { in weirs }\end{array}$ & $\begin{array}{l}\text { cabled and } \\
\text { in weirs }\end{array}$ & $\begin{array}{l}\text { anchored as } \\
\text { deflectors }\end{array}$ & $\begin{array}{l}\text { unanchored, } \\
\text { by crane }\end{array}$ & $\begin{array}{l}\text { unanchored, } \\
\text { by crane }\end{array}$ & $\begin{array}{l}\text { unanchored, } \\
\text { by helicopter }\end{array}$ \\
\hline No. pieces LWD added & 18 & 25 & 48 & 300 & 80 & 280 \\
\hline Approx. cost $(\$ / m)^{*}$ & $\$ 350^{(1)}$ & NA & $\$ 160^{(2)}$ & $\$ 580^{(2)}$ & $\$ 120^{(2)}$ & $\$ 280^{(2)}$ \\
\hline Project Objectives & $\mathbf{X}$ & $\mathbf{X}$ & $\mathbf{X}$ & $\mathbf{X}$ & $\mathbf{X}$ & \\
\hline $\begin{array}{l}\text { Sediment and erosion } \\
\text { control }\end{array}$ & $\mathbf{X}$ & $\mathbf{X}$ & & $\mathbf{X}$ & $\mathbf{X}$ & $\mathbf{X}$ \\
\hline Habitat enhancement & $\mathbf{X}$ & $\mathbf{X}$ & $\mathbf{X}$ & & $\mathbf{X}$ & $\mathbf{X}$ \\
\hline
\end{tabular}

Costs based on preliminary estimates of construction costs divided by project length: (1) source: Parametrix 1988;

(2) source: KCDNR (1995, 1997). 
Table 2. Watershed and stream characteristics

\begin{tabular}{|c|c|c|c|c|c|c|}
\hline & Forbes & Thornton & Swamp & H. Hills & L. Jacob's & Soosette \\
\hline $\begin{array}{l}\text { Stream characteristics } \\
\text { Avg. bankfull width (m) } \\
\text { Bed slope }\end{array}$ & $\begin{array}{c}3.5 \\
0.037 \\
\end{array}$ & $\begin{array}{c}5.4 \\
0.006 \\
\end{array}$ & $\begin{array}{c}10.4 \\
0.005\end{array}$ & $\begin{array}{c}4.1 \\
0.046 \\
\end{array}$ & $\begin{array}{c}6.4 \\
0.028 \\
\end{array}$ & $\begin{array}{c}8.7 \\
0.019 \\
\end{array}$ \\
\hline $\begin{array}{l}\mathrm{D}_{50}(\mathrm{~mm}) \\
\text { Upstream drainage }\left(\mathrm{km}^{2}\right)\end{array}$ & $\begin{array}{c}14(26) \\
3.5\end{array}$ & $\begin{array}{c}18 \\
25.4\end{array}$ & $\begin{array}{c}14 \\
53.6\end{array}$ & $\begin{array}{c}11 \\
2.2\end{array}$ & $\begin{array}{c}39 \\
11.1\end{array}$ & $\begin{array}{l}51 \\
13\end{array}$ \\
\hline $\begin{array}{l}\text { Percent upstream develo } \\
\text { Watershed } \\
\text { Riparian buffer }(100 \mathrm{~m})\end{array}$ & $\begin{array}{l}82 \% \\
70 \%\end{array}$ & $\begin{array}{l}93 \% \\
75 \%\end{array}$ & $\begin{array}{l}72 \% \\
47 \%\end{array}$ & $\begin{array}{l}62 \% \\
44 \%\end{array}$ & $\begin{array}{l}52 \% \\
43 \%\end{array}$ & $\begin{array}{c}58 \% \\
34 \%(45 \%) *\end{array}$ \\
\hline $\begin{array}{l}\text { Basin relief (m) } \\
\text { Basin gradient (relief / } \\
\quad \text { basin length) }\end{array}$ & $\begin{array}{c}45 \\
0.009\end{array}$ & $\begin{array}{c}45 \\
0.0045\end{array}$ & $\begin{array}{c}150 \\
0.003\end{array}$ & $\begin{array}{c}45 \\
0.0022\end{array}$ & $\begin{array}{c}45 \\
0.0075\end{array}$ & $\begin{array}{c}45 \\
0.0075\end{array}$ \\
\hline
\end{tabular}

*Percent development in riparian buffer beginning at upstream end of the project.

\section{Installed LWD frequency, size, and position}

A section of stream, at least 20 times the bankfull width, was surveyed in the project reach and just upstream of the project. All pieces of wood greater than 10-cm diameter and longer than $1 \mathrm{~m}$ in any portion of the bankfull channel were counted, based on criterion used by Montgomery et al. (1995), Greenberg (1995), and May (1996). Root wads greater than $0.02 \mathrm{~m}^{3}$ in volume were also included. The diameter and length of every piece was estimated; every 5-10 pieces the lengths and widths were measured with a tape to calibrate the visual estimate. "Key pieces" were also identified; they are those pieces of LWD defined as being independently stable within the bankfull channel (i.e., not held or trapped by other material) and retaining or having the ability to retain other LWD (WFPB 1997).

\section{Pools}

Residual pool depths (RPDs) were measured in the field and calculated from longitudinal thalweg surveys. RPD is the difference between depth of water in the pool and at the top of the downstream riffle (Lisle 1987). Only pools with a RPD at least $25 \%$ of the bankfull depth and minimum pool length at least $10 \%$ of the bankfull width were included (Montgomery et al. 1995). Pre-project information on pool numbers was taken from the Fish Habitat Relation (FHR) surveys conducted by the King County Water and Land Resources Division. The influence of LWD on the formation of pools was determined by field observation, with two categories identified: pools formed by wood and pools formed by some other mechanism (such as scour around a boulder or lateral scour against an armored bank.

\section{Biology}

Benthic invertebrate samples were collected at five of the six rehabilitation projects in a companion study by Morley (2000) and analyzed according to the Benthic Index of Biological Integrity (B-IBI; Karr and Chu 1999). Sample sites were located on riffles just upstream and downstream of the project reaches. The B-IBI is a multimetric index that uses 5 different categories of measures of macro-invertebrate samples (taxa richness, community composition, feeding groups, tolerance/intolerance, dominance) to assign a score that ranges from 10 (very poor) to 50 (excellent). 
RESULTS

Installed LWD frequency, size, and position

LWD frequency was used to compare project-reach and upstream conditions to those of reference streams (Montgomery et al., 1995; May, 1996). In the study reaches, LWD loadings were highest — in the range of the "least degraded urban streams" — in the projects using unanchored LWD (Figure 1). Only one of the streams (Hollywood Hills) had an LWD frequency considered ideal for a natural stream (Bisson et al., 1987; WAFPB, 1997). At the projects where the wood was anchored, LWD loadings were still typical of degraded urban streams and clear-cut. No logs of sufficient size to be "key" pieces were added to the widest stream (Soosette), where LWD was not anchored.

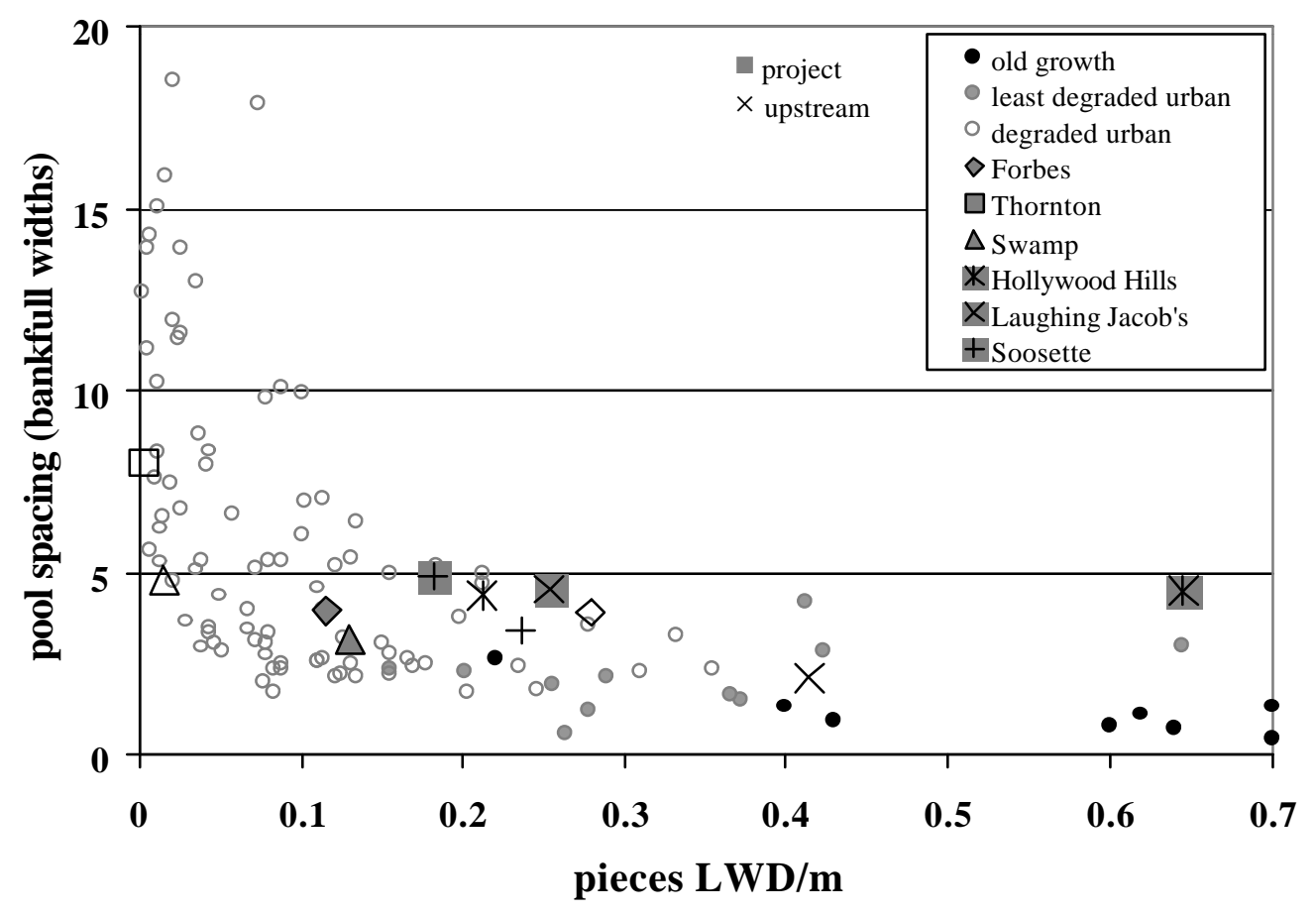

Figure 1. Pool spacing vs. LWD loading — comparison with reference sites, and between "project" and "upstream" sites.

\section{LWD mobility}

Where the post-construction interval had experienced one or more 2-year to 10-year discharges, no anchored LWD moved at any of the project reaches. At the one unanchored LWD project where over 50\% of the LWD were considered key pieces (Hollywood Hills), there was no significant LWD movement.

In the two unanchored LWD projects with few or no key pieces, however, LWD movement was documented. Two unanchored logs at Swamp Creek were transported over $300 \mathrm{~m}$ and out of the project reach. After a 10-yr flow event in Laughing Jacob's Creek, numerous pieces of 
LWD were either transported downstream (most 20-30 m), moved across the channel, or abandoned on adjacent banks by high flows. Small-diameter logs with roots attached and placed entirely in the channel appeared to move further than larger-diameter smooth logs placed perpendicular to the channel and partly resting on the banks. At Soosette Creek, dozens of smooth logs (as well as logs with branches drilled into them, ostensibly to mimic the form of "real" trees), moved several 10's of meters. Most logs were found in piles where they had been carried.

\section{Pool spacing, formation, and depth}

In the project reaches, pool spacing was insensitive to LWD loading (Figure 1). At three sites (Hollywood Hills and Laughing Jacob's and Soosette creeks), pool spacing was wide compared to least-degraded urban streams with the same amount of LWD. Forbes and Swamp creeks, where the LWD was anchored, had pool spacings most similar to those found in forested and least-degraded urban streams despite low LWD frequencies. Wherever pre-project data were available, pool spacing was reduced in all projects (Figure 2). At Soosette and Swamp creeks, pool spacing narrowed only slightly, however.

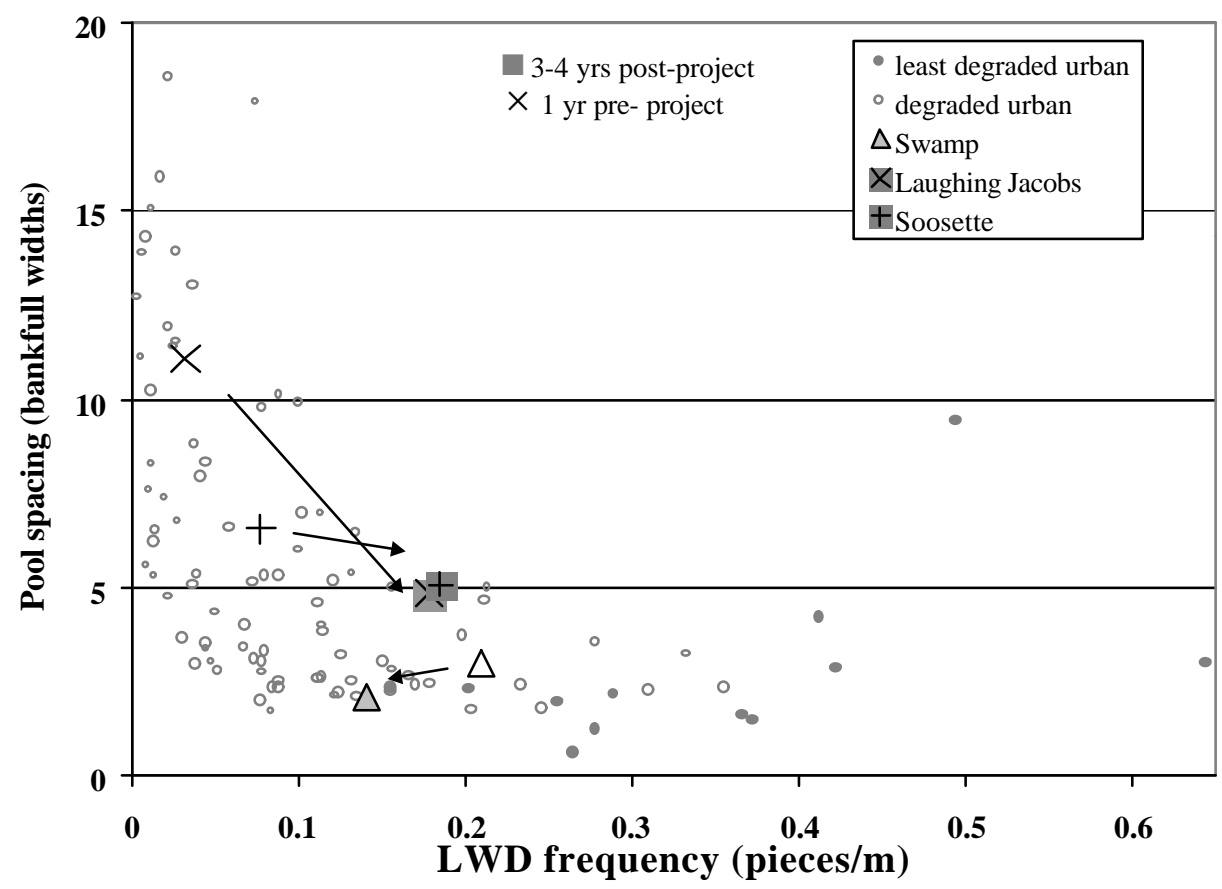

Figure 2. Pool spacing vs. LWD Frequency over time at Laughing Jacob's and Soosette creeks (King County's FHR survey data; KCDNR 1997)

\section{Sediment storage and grade control}

Although the indirect influence of LWD on sediment retention was not measured precisely, about one-third of the channel sediment storage appeared to be associated with LWD at most 
sites. Sediment storage usually increased with an increase in LWD frequency in a given stream. There were few locations in each stream where LWD retained sediment in the form of a discrete wedge. Added LWD contributed most to grade control (11-23\%) on the highest gradient streams (Forbes Creek, Hollywood Hills and Laughing Jacob's Creek; slopes = 0.026-0.046) where the wood was spanning the full width of the channel. On the low-gradient streams (Thornton and Swamp creeks; slopes $=0.005-0.008)$, LWD contributed little to grade control $(0-6 \%$ of total elevation loss).

\section{Biological Conditions}

Almost uniformly, the sites showed no significant improvement in B-IBI score (i.e. at least 4 point difference) between upstream and downstream of the project (Table 3). One partial exception was at Soosette Creek, where scores improved at the downstream site. Yet the upstream site was over $1.5 \mathrm{~km}$ upstream of the downstream site, and the pre-project score at this same upstream site was also significantly worse than the pre-project score was at the downstream end of the project (Greenberg 1995, Morley 1999).

Table 3. B-IBI scores at project sites; 1998 data from Morley (2000)

\begin{tabular}{|l|cccccc|}
\hline & Forbes & Thornton & Swamp & $\begin{array}{c}\text { Hollywood } \\
\text { Hills }\end{array}$ & $\begin{array}{c}\text { Laughing } \\
\text { Jacob's }\end{array}$ & Soosette \\
\hline Project reach & 16 & 12 & 26 & NA & 22 & 45 \\
Upstream reach & 16 & 10 & 24 & NA & $32^{3}$ & $(36,34)^{2}$ \\
Pre-project & & & & & & 36 \\
\hline
\end{tabular}

1 Sampled by Morley in 1999 at a more remote riffle $40 \mathrm{~m}$ upstream of the 1998 site.

2 Sampled by King County in 1995 and 1998 approximately 440 m upstream of Morley's site.

3 Sampled by Morley in 1999

4 Sampled in 1993 by Greenberg (1995) approximately 180 m upstream of Morley's site.

Local physical channel characteristics, such as LWD frequency or pool spacing, generally had no relation to the B-IBI score. There appeared to be only a very weak positive relationship between B-IBI score and indicators of bank and bed stability or median grain size. In contrast, B-IBI scores showed a strong correlation to the percentage of urban development in the basin. The scores for all but one of the projects fall in the middle of the range of that found by Morley (2000) on streams with similar levels of development. Only Soosette Creek shows an unexpectedly high score for the level of development in the watershed that might be attributable, in part, to the influence of the LWD project.

\section{DISCUSSION}

Best Streams for Effective LWD Placement

In general, LWD has the greatest influence and range of functions on moderate-slope (0.010.03) alluvial channels classified morphologically as pool-riffle or plane-bed (Montgomery et al. 1995, Montgomery and Buffington 1997, Beechie and Sibley 1997). Particularly in PSL streams, which tend to lack boulder or bedrock obstructions, and in urban streams, lacking deep- 
rooted woody bank vegetation, LWD is the primary pool-forming mechanism. In wide lowslope channels, LWD addition may have less influence, particularly if resistant banks allow lateral scour to create free-formed pools. Where the riparian zone has been disturbed, however, critical bank cohesion provided by deep-rooted woody vegetation may be absent and added LWD can provide hard points needed to scour pools as well as helping to maintain channel form and position.

\section{Evaluation of Project Design}

Limited project effectiveness may result from either of two causes: projects were built with an inadequate design, or "appropriate" designs nonetheless yield inadequate results. Some criteria for the design of in-stream structures using LWD can be extracted from the research on the function of LWD in forested streams. Such "design criteria" can be compared with conditions at the six rehabilitation projects to evaluate the success of each project in meeting them (Table 4). So, for example, anchored LWD used in projects rarely met the size criteria for "key pieces." Yet where anchored, a higher percentage of the LWD significantly obstructed the flow, was in contact with the bed, and was adequately spaced (F, T, Sw) than where unanchored (HH, LJ, So).

Table 4. Design criteria inferred from reported stable LWD in natural channels.

\begin{tabular}{|c|c|c|}
\hline & WD Design Crit & \\
\hline description & Value & Reference \\
\hline $\begin{array}{l}\text { Key piece sizes \& frequency } \\
\mathrm{W}_{\mathrm{bk}}=3-5 \mathrm{~m}^{(1)} \\
\mathrm{W}_{\mathrm{bk}}=6-10 \mathrm{~m}^{(1)} \\
\text { Min. \# key pieces per meter }^{(1)} \\
\mathrm{W}_{\mathrm{bk}}=0-5 \mathrm{~m}^{(2)} \\
\mathrm{W}_{\mathrm{bk}}=6-10 \mathrm{~m}^{(2)} \\
\text { Min. \# key pieces per } \mathrm{W}_{\mathrm{bk}}{ }^{(2)}\end{array}$ & $\begin{array}{c}0.4 \mathrm{~m}^{3} \\
0.8 \mathrm{~m}^{3} \\
0.13 \mathrm{LWD} / \mathrm{m} \\
1 \mathrm{~m}^{3} \\
2.4 \mathrm{~m}^{3} \\
0.3 \mathrm{LWD} / \mathrm{W}_{\mathrm{bk}}\end{array}$ & $\begin{array}{c}\text { Bisson et al. } 1987 \\
\text { Bisson et al. } 1987 \\
\text { Bisson et al. } 1987 \\
\text { WFPB } 1997 \\
\text { WFPB } 1997 \\
\text { WFPB } 1997\end{array}$ \\
\hline $\begin{array}{l}\text { Obstruction angle or width } \\
\text { angled to flow; partially elevated } \\
\text { obstructing flow or } \mathrm{W}_{\mathrm{bk}}(4) \\
\text { obstructing flow }^{(5)}\end{array}$ & $\begin{aligned} & 90^{\circ} \\
&> 30 \% \\
&> 10 \% \\
&\end{aligned}$ & $\begin{array}{l}\text { Cherry and Bilby } 1989 \\
\text { Lisle } 1986 \\
\text { Cherry and Bilby } 1989 \\
\end{array}$ \\
\hline $\begin{array}{l}\text { Burial and angle } \\
\text { angled to flow; mostly buried } \\
(1)\end{array}$ & $<30^{\circ}$ & Bisson et al. 1987 \\
\hline $\begin{array}{l}\text { Cross-bed position } \\
\text { angled to flow; on bed } \\
\end{array}$ & $90^{\circ}$ & Gippel et al. 1996 \\
\hline $\begin{array}{l}\text { Log spacing } \\
\text { Spacing in any direction } \\
\text { downstream distance }^{(5)}\end{array}$ & $\begin{array}{c}>10 \log \text { dia. } \\
>3 \mathrm{~W}_{\mathrm{bk}}\end{array}$ & $\begin{array}{c}\text { Gippel et al. } 1996 \\
\text { Lisle } 1986 \\
\end{array}$ \\
\hline $\begin{array}{l}\text { Log loading } \\
\text { Volume per channel area }^{(4)} \\
\text { pieces per channel area }^{(6)}\end{array}$ & $\begin{array}{l}0.01 \mathrm{~m}^{3} / \mathrm{m}^{2} \\
0.035 \# / \mathrm{m}^{2}\end{array}$ & $\begin{array}{c}\text { Lisle } 1986 \\
\text { Montgomery et al. } 1995\end{array}$ \\
\hline
\end{tabular}

Meeting design criteria is critical only if these criteria are relevant to attaining actual project objectives. Table 5 shows the extent to which a specific criterion (Table 4) was met, and whether the associated objective was generally achieved. For example, "obstruction width" was an important factor in forming pools at most sites, because when these suggested criteria were 
met (shaded box) these objectives were usually met $(\boldsymbol{})$. Conversely, "key piece frequency" is probably also important, because at most sites the criterion were not met (white box) and neither were the associated objectives (- ).

Most criteria were not sufficient to ensure that specific project objectives can be met. For example, the implied criteria for cross-bed position and burial of LWD were achieved at several projects (shaded box) but the project objectives were still not attained (- ). The same was true of log loading--even adequate amounts of LWD did not ensure that all projects objectives would be met.

Table 5. Objectives and LWD design criteria met and not met at project sites*

\begin{tabular}{|c|c|c|c|c|c|c|c|}
\hline \multirow{2}{*}{$\begin{array}{c}\text { LWD Design Criteria } \\
\text { And Objectives }\end{array}$} & \multicolumn{6}{|c|}{ Objectives and criteria met or not } & \multirow{2}{*}{$\begin{array}{c}\text { Suitability of design criteria for } \\
\text { Meeting project objectives }\end{array}$} \\
\hline & $\mathbf{F}$ & $\mathbf{T}$ & Sw & HH & LJ & So & \\
\hline $\begin{array}{l}\text { Obstruction width } \\
\text { for pool formation } \\
\end{array}$ & $?$ & $?$ & 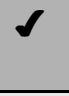 & $\boldsymbol{J}$ & $\mathcal{J}$ & $\mathcal{J}$ & $\begin{array}{l}\text { Important for pool formation, whether } \\
\text { as a result of size or position. }\end{array}$ \\
\hline $\begin{array}{l}\text { Log spacing for } \\
\text { hydraulically } \\
\text { independent effect }\end{array}$ & $\checkmark$ & 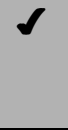 & - & - & - & 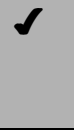 & $\begin{array}{l}\text { Important in maximizing effect of } \\
\text { added LWD. }\end{array}$ \\
\hline $\begin{array}{l}\text { Key piece frequency } \\
\text { for stability } \\
\text { for influencing flow }\end{array}$ & - & - & $?$ & 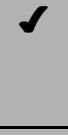 & - & - & $\begin{array}{l}\text { Important for stability of unanchored } \\
\text { LWD, and for flow influence and } \\
\text { debris trapping of anchored LWD. }\end{array}$ \\
\hline $\begin{array}{l}\text { Log loading } \\
\text { for project objectives }\end{array}$ & - & - & - & - & - & - & $\begin{array}{l}\text { Probably important, but depends on } \\
\text { LWD position and size. }\end{array}$ \\
\hline $\begin{array}{l}\text { Cross-bed position } \\
\text { for sediment retention }\end{array}$ & - & - & - & - & - & - & $\begin{array}{l}\text { Probably important for sediment } \\
\text { retention, but not sufficient. }\end{array}$ \\
\hline $\begin{array}{l}\text { Burial and angle } \\
\text { for stability }\end{array}$ & NA & NA & $\boldsymbol{J}$ & $\mathcal{J}$ & - & - & $\begin{array}{l}\text { LWD burial and position important } \\
\text { for stabilizing smaller pieces. }\end{array}$ \\
\hline $\begin{array}{l}\text { Obstruction angle } \\
\text { for pool formation }\end{array}$ & $?$ & $?$ & 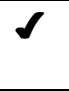 & $?$ & 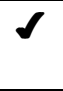 & 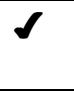 & $\begin{array}{l}\text { Irrelevant for pool formation, } \\
\text { particularly if LWD is too small. }\end{array}$ \\
\hline
\end{tabular}

Key:

\begin{tabular}{|c|c|c|c|c|c|}
$\begin{array}{c}\text { } \text { objective } \\
\text { usually met }\end{array}$ & $\begin{array}{c}\text { - objectives } \\
\text { usually not met }\end{array}$ & criteria met & $\begin{array}{c}\text { less strict criteria } \\
\text { met }\end{array}$ & $\begin{array}{c}\text { Criteria } \\
\text { not met }\end{array}$ & $\begin{array}{c}\text { ? not } \\
\text { determined }\end{array}$ \\
\hline
\end{tabular}

* Forbes (F), Thornton (T), Swamp (Sw), Hollywood Hills (HH), Laughing Jacob’s (LJ), Soosette (So).

\section{Watershed Controls on the effectiveness of in-stream structures}

At the projects in the least degraded watersheds (52-58\% development), there was little evidence that the urban-modified flow pattern were undermining in-stream efforts to enhance the channel. Some LWD was mobilized in these project reaches, but most of these unstable pieces were either smooth poles or clearly too small. Local incision was occurring in these reaches as well, but mostly by entrenchment through recently deposited sediment. Any downstream deposition primarily resulted from remobilization of materials deposited within the upper project, not as a result of high sediment loads from upstream in the watershed. An undeveloped riparian corridor, ubiquitous along the project reaches in the least developed basins, also aided the channel enhancement effort. 


\section{CONCLUSIONS}

This work evaluates the effectiveness of in-stream projects using LWD in urban streams where no systematic effort had been made to reduce degradation at the watershed scale. These types of projects are increasingly popular, particularly in the Pacific Northwest, where LWD is recognized as an important element in physical habitat important for salmonids. Yet there is little evidence that these in-stream projects can reverse even the local expressions of watershed degradation in urban channels.

Six urban stream rehabilitation projects using LWD were investigated here, and four questions were posed:

- Does in-stream placement of LWD produce physical channel characteristics typical of streams in less disturbed watersheds?

- Does biological integrity improve after LWD is added?

- Does watershed disturbance exert an equivalent or greater effect on the physical and biological recovery of the channel than the local in-channel conditions addressed by the LWD?

- How can LWD project designs be improved?

Adding LWD to urban streams produces physical characteristics more like those in forested and "least-disturbed urban" streams. Comparing pre- with post-project data, distances between pools decreased after LWD was added. Where pre-project data are not available, the high proportion of pools formed by added LWD also suggests that the projects reduced the pool spacing. Artificially added LWD is apparently not always as efficient in forming pools as the natural wood, however.

Some specific objectives were achieved by in-stream LWD additions, while others were not. Increased pool habitat and increased channel complexity were achieved in most of the projects. Stabilizing or retaining sediment to reduce downstream sedimentation and flooding, in contrast, was not possible by adding LWD to the channel. The influence of watershed disturbance on the physical channel response was particularly evident, and in several instances it simply overwhelmed any potential benefits of LWD. High sediment loads buried some LWD, high flows transported seemingly appropriately sized LWD out of the channel, and high flows caused incision beneath the influence of LWD formerly within the bankfull channel.

Biological integrity, as measured by the Benthic Index of Biological Integrity (B-IBI), did not change in response to added LWD. In the one stream where the upstream had a significantly lower score than the downstream site (Soosette Creek), the setting of the upstream site was not comparable to the project site with regard to roads, stormwater discharges, recent construction, and other development. At the only other project where upstream and downstream B-IBI scores were significantly different they worsened downstream, in consort with the physical conditions. These scores indicate that although projects several hundred of meters long may improve physical habitat in a stream reach over the evaluated time scales of 2-10 years, they do not contribute to improvement in biologic conditions of the benthos.

\section{Management implications}

Adding LWD to a degraded stream in an urban setting will not guarantee that it will perform the functions provided in undisturbed stream systems. Whereas adding LWD is likely to achieve a number of specific objectives, a proliferation of in-stream LWD projects will not ensure habitat protection or biological recovery. Therefore, it is critical to identify the primary factors causing degradation in a reach; evaluate existing channel conditions; and determine which, if any, objectives can be met with in-stream enhancement projects. Not all placement 
techniques and types of LWD are equally suited to meet specific design objectives. The tradeoffs between costs of anchoring smaller LWD or placing unanchored larger LWD should be considered against the importance of each objective. Finally, recognize that adding LWD to urban streams may not be physically detrimental, but resources should not be allocated to stream projects in the name of stream ecosystem enhancement while overlooking the control of source problems in the watershed. 